\title{
PELATIHAN PERAWATAN MESIN JAHIT DALAM RANGKA RE-EKSISTENSI KELOMPOK SWADAYA MASYARAKAT (KSM) SEPAKAT DALAM PENGOLAHAN SAMPAH DI KELURAHAN PASAR UJUNG KABUPATEN KEPAHIANG
}

\author{
Ahmad Fauzan Suryono ${ }^{1}$, Nyayu Neti Arianti², Reflis ${ }^{2}$ \\ 1Fakultas Teknik Universitas Bengkulu, \\ 2Fakultas Pertanian Universitas Bengkulu \\ ahmadfauzan@unib.ac.id.
}

\begin{abstract}
The Non-Governmental Organization (KSM) Sepakat is a form of community participation in waste processing. This KSM is located in Pasar Ujung Subdistrict, Kepahiang Regency, Bengkulu Province. KSM Sepakat was established in 2010 and from 2017 has stoped and vacuum from all activity to now. One of the factors that cause this vacuum is the damage to production equipment, including components in sewing machines. The lack of assistance and guidance from the local government has caused the members' motivation to decrease so that production has reduced too. One of the efforts to re-exist and reproduce again is sewing machine repair training for all KSM members. This training aims to ensure that each member has basic skills in repairing sewing machines so that if damage occurs, it will not interfere with the production of waste processing. The method used in this training is through lectures, demonstrations, discussion, and direct practice. From the results of the questionnaire, it can be seen that the participants can understand the material well, and the material provided is following the problems in the field. Apart from that, from the questionnaire, it can be seen that the training participants are again committed to activating the activities at KSM Sepakat
\end{abstract}

Keywords: KSM, waste, re-existence, sewing machine.

\begin{abstract}
Abstrak
Kelompok Swadaya Masyarakat (KSM) Sepakat merupakan salah satu bentuk partisipasi masyarakat dalam pengolahan sampah. KSM ini terletak di Kelurahan Pasar Ujung Kecamatan Kepahiang Kabupaten Kepahiang. KSM Sepakat berdiri pada tahun 2010 dan dari tahun 2017 mengalami kevakuman kegiatan hingga saat ini. Salah satu faktor yang menyebabkan kevakuman ini adalah rusaknya peralatan-peralatan produksi, diantaranya adalah komponen pada mesin jahit. Selain itu kurangnya pendampingan dan pembinaan dari pemerintah setempat yang menyebabkan motivasi dari anggota menjadi turun sehingga produksi menjadi menurun. Salah satu upaya reeksitensi KSM ini supaya berproduksi lagi adalah dengan melakukan pelatihan reparasi mesin jahit kepada semua anggota KSM. Pelatihan ini bertujuan supaya setiap anggota memiliki kemampuan dasar dalam reparasi mesin jahit sehingga apabila terjadi kerusakan maka tidak akan mengganggu jalannya produksi pengolahan sampah. Metode yang dilakukan dalam pengabdian masyarakat ini adalah melalui ceramah, demonstrasi, tanya jawab dan praktek langsung di lapangan. Dari hasil kuisioner terlihat bahwa peserta dapat memahami materi dengan baik dan materi yang diberikan sudah sesuai dengan permasalahan yang ada di lapangan. Selain itu dari kuiosiner terlihat bahwa peserta pelatihan kembali berkomitmen untuk mengaktifkan kegiatan di KSM Sepakat
\end{abstract}

Kata kunci: KSM, Limbah, re-exixtence,Mesin Jahit 
Ahmad Fauzan Suryono, dkk. Pelatihan Perawatan Mesin Jahit Dalam Rangka ...

\section{PENDAHULUAN}

Isu mengenai sampah semakin menjadi perhatian semua kalangan saat ini, baik di kalangan pemerintah maupun di kalangan anggota masyarakat sendiri (Asteria,2016). Peningkatan kebutuhan dan konsumsi rumah tangga sangat memberikan dampak yang signifikan dalam produksi sampah terutama sampah plastik. Sampah plastik ini sifatnya susah diurai oleh tanah sehingga dapat menyebabkan degradasi pada lingkungan (Lintang Permata, 2017). Penyelesaian masalah sampah masih terus membutuhkan perhatian besar baik dari pemerintah maupun dari segenap anggota masyarakat. Bagaimanapun masalah sampah menjadi masalah semua kalangan, sehingga semua pihak bertanggung jawab dan memiliki peran yang penting untuk mencari solusi (Nining, 2016). Pengelolaan sampah, terutama sampah plastik dengan prinsip Reduce, Reuse dan Recycle (3R) harus menjadi gerakan yang mendunia. Prinsip pengelolaan sampah terpadu meliputi pengumpulan, pengangkutan, pengolahan hingga pendaur-ulangan dapat dilakukan pada tingkatan yang paling rendah, yakni rumahtangga atau pun kelompok-kelompok swadaya masyarakat. Jika Kelompok Swadaya Masyarakat (KSM) digerakkan untuk mengelola sampah, maka permasalahan sampah dapat diatasi sekaligus menciptakan lapangan kerja dan peningkatan pendapatan masyarakat Pusat Penelitian dan Pengembangan Permukiman Balitbang Kementerian Pekerjaan Umum RI (2010). Ediana (2018) menyatakan bahwa program pemberdayaan masyarakat berhubungan dengan keberhasilan pengolaan sampah 3R.

Salah satu KSM yang mengelola sampah sebagai unit usahanya adalah KSM Sepakat di Kelurahan Pasar Ujung
Kecamatan Kepahiang Kabupaten Kepahiang Provinsi Bengkulu yang dibentuk pada tahun 2010. KSM Sepakat bekerjasama dengan Satuan Kerja Pengembangan Penyehatan Lingkungan Permukiman Dinas Pekerjaan Umum Provinsi Bengkulu (Gambar 1).

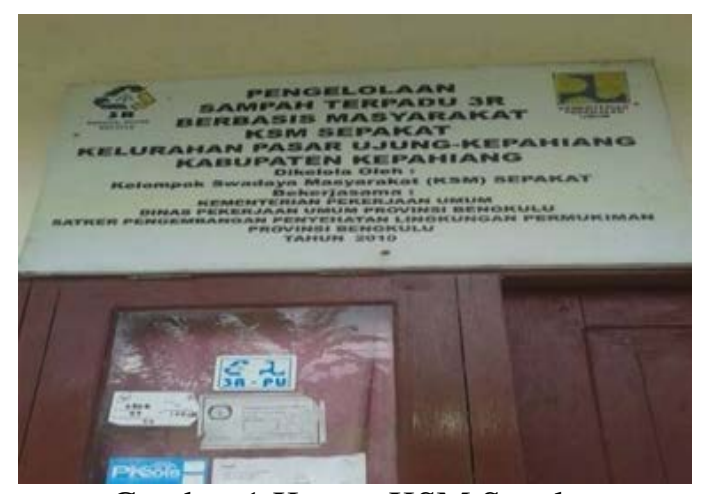

Gambar 1 Kantor KSM Sepakat

Sebagian besar anggota KSM adalah ibu-ibu rumah tangga di Kelurahan Pasar Ujung. KSM ini melakukan kegiatan-kegiatan : 1). Pengelolaan terpadu sampah rumahtangga dengan prinsip 3R, dengan cara mengumpulkan dan mengolah sampah menjadi barang-barang bermanfaat hasil daur ulang sampah plastik antara lain tas, celemek, sandal, dompet, tikar, dan lain-lain seperti terlihat pada gambar 2dan 2). Pengelolaan bank sampah yang bernama bank sampah Sehasen

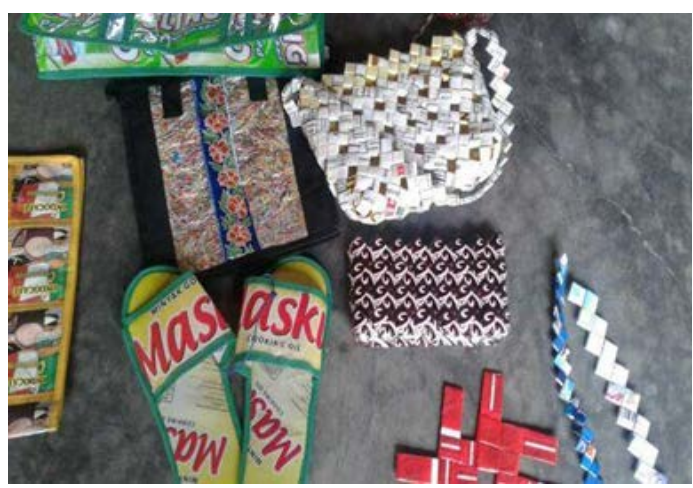

Gambar 2. Produk-produk Daur Ulang Sampah yang Dihasilkan KSM Sepakat 
Kegiatan KSM ini sempat berjalan dengan baik selama tujuh tahun sejak berdirinya pada tahun 2010. Peralatan-peralatan yang tersedia seperti mesin jahit, mesin pencacah sampah organik, kendaraan roda dua serta fasilitas tempat dan bangunan tersedia dan dapat digunakan dengan baik. Pemasaran produk yang dihasilkan lancar, karena terdapat beberapa rekanan penampung hasil daur ulang sampah yang dihasilkan KSM Sepakat. Selama tujuh tahun beroperasi, bank sampah Sehasen juga berjalan dengan baik. Nasabahnya adalah sekolahsekolah dan kantor-kantor instansi di Kabupaten Kepahiang, serta masyarakat Kelurahan Pasar Ujung dan sekitarnya. Namun sangat disayangkan sejak tahun 2017 kegiatan KSM Sepakat tidak berlanjut hingga saat ini. Terhentinya kegiatan KSM Sepakat tentu berimbas kepada permasalahan sampah yang selama KSM berjalan sudah dapat diatasi, sekarang menjadi kembali harus mendapatkan perhatian khusus kembali.

Permasalahan yang dirasakan oleh para pengurus dan anggota KSM yang menyebabkan kegiatan-kegiatan KSM yang meliputi pengelolaan sampah terpadu 3R dan bank sampah Sehasen menjadi terhenti adalah :

1. Sampah yang dikumpulkan dari masyarakat masih tercampur antara sampah organik dan sampah anorganik, sehingga menyulitkan KSM harus memilahnya terlebih dahulu sebelum diolah lebih lanjut.

2. Mesin jahit tidak dapat beroperasi dengan baik karena ada beberapa komponennya yang rusak.

3. Kurangnya pendampingan dan pembinaan dari pemerintah setempat sehingga kemampuan pengelolaan juga menjadi rendah.

4. Permasalahan-permasalahan lain yang belum mampu diidentifikasi oleh para anggota dan pengurus.

\begin{abstract}
Berdasarkan identifikasi permasalahan tersebut maka dilakukanlah kegiatan pengabdian masyarakat di KSM Sepakat. Adapun kegiatan yang dilakukan adalah Memberikan pelatihan kepada pengurus dan anggota KSM Sepakat tentang reparasi dan mesin jahit. Dengan adanya pelatihan ini diharapkan kegiatan pendaur ulangan sampah dapat berjalan kembali. Selain itu diharapkan dari pelatihan ini anggota KSM Sepakat memiliki keterampilan dasar dalam memperbaiki mesin jahit. Apabila dalam produksi daur ulang sampah terdapat kendala pada mesin jahit dapat langsung diperbaiki sendiri sehingga tidak mengganggu kegiatan produksi. Selain itu dari kegiatan ini dapat menggerakkan kembali peran KSM Sepakat dalam pengelolaan sampah terpadu 3R (membuat produk daur ulang sampah plastik) sekaligus menggerakkan kembali peran KSM Sepakat dalam mengelola bank sampah Sehasen
\end{abstract}

\section{METODE}

Kegiatan penyuluhan dan pelatihan bagi masyarakat khususnya anggota KSM Sepakat di Kabupaten Kepahiang Provinsi Bengkulu ini dilakukan dengan metode Belajar sambil Melakukan (learning by Doing) yang dibagi dalam beberapa kegiatan yaitu:

\section{Perencanaan kegiatan program penyuluhan dan pelatihan.}

Kegiatan ini meliputi survei lokasi, identifikasi masalah, penyusunan proposal kegiatan dan perencanaan jadwal kegiatan.

\section{Pelaksanaan penyuluhan.}

Kegiatan ini dilakukan dalam bentuk ceramah atau pemaparan dari 
Ahmad Fauzan Suryono, dkk. Pelatihan Perawatan Mesin Jahit Dalam Rangka ...

pemateri yang diikuti dengan diskusi serta tanya jawab dengan peserta dalam rangka mentransfer pengetahuan dan keterampilan perawatan mesin jahit.

\section{Kegiatan Pelatihan.}

Kegiatan pelatihan diberikan supaya materi materi yang disampaikan pada saat penyuluhan dapat diserap dengan baik oleh peserta. Peserta diberikan modul untuk memudahkan dalam menerima instruksi ketika pelatihan. Modul ini berisi tentang pengetahuan tentang komponen mesin jahit, dan langkah langkah dalam perbaikan mesin jahit. Instruksi pelatihan dilakukan secara verbal dengan memberikan contoh-contoh perbaikan pada mesin jahit. Peserta mengamati langsung kegiatan mulai dari pembongkaran komponen yang rusak sampai dengan melakukan perbaikan dari permasalahan pada mesin jahit. Setelah diberikan penjelasan secara verbal, peserta diberi kesempatan untuk mencobakan secara langsung. Dalam sesi pelatihan ini, dilakukan juga kegiatan tanya jawab. Hal ini bertujuan untuk memberi kesempatan kepada peserta untuk menanyakan hal-hal yang masih belum dimengerti. Pada bagian akhir dari pelatihan ini, peserta mengisi kuisioner yang telah disusun sebelumnya untuk mengetahui respon dari peserta terhadap pelatihan yang diadakan.

\section{Pembuatan laporan kegiatan pengabdian}

Pembuatan laporan kegiatan pengabdian yang meliputi evaluasi langsung dari tim pengabdian maupun evaluasi berdasarkan isian kuisioner dari peserta. Penilaian dari peserta berupa data kualitatif dan meminta mereka memberikan respon SS (Sangat Setuju), S (Setuju), R (Ragu-ragu), TS (Tidak Setuju), dan STS (Sangat Tidak
Setuju) dengan pernyataan yang ada pada kuisioner.

\section{HASIL DAN PEMBAHASAN}

Tahap persiapan pada kegiatan ini meliputi survei lokasi, identifikasi masalah, penyusunan proposal kegiatan dan perencanaan jadwal kegiatan. Tahap persiapan dimulai dengan melakukan observasi ke KSM Sepakat. Pada saat observasi ini dilakukan wawancara dengan pimpinan KSM Sepakat untuk mengidentifikasi permasalahan yang ada di sana. Dari wawancara ini dicari penyebab kenapa KSM ini vakum dari kegiatan beberapa tahun belakangan. Pada tahapan persiapan ini dirancanglah kegiatan yang akan dilaksanakan untuk memotivasi anggota beraktifitas lagi.salah satu kgiatan yang disepakati adalah pelatihan untuk perawatan mesin jahit. Hal itu dilakukan karena salah satu kendala selama ini adalah peralatan mesin jahit yang sering mengalami kerusakan. Dalam langkah persiapan ini juga disepakati bahwa peralatan mesin jahit akan disediakan oleh tim pengabdian. Selain itu bahan serta alat presentasi juga disiapkan oleh tim pengabdian sedangkan prasarana dan pengumpulan peserta akan dibantu oleh pimpinan KSM untuk disosialisasikan kepada anggota.

Langkah kedua pada tahapan ini adalah melakukan koordinasi dalam tim untuk penyiapan proposal dan persiapan modul pelatihan. Bahan pelatihan dibuat sesederhana mungkin dengan bahasa yang gampang dipahami oleh masyarakat awam. Modul pelatihan diberikan kepada peserta pelatihan untuk memudahkan mereka dalam mengikuti kegiatan tersebut.

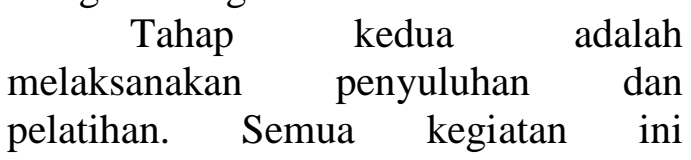


dilaksanakan dengan menerapkan standar protokol Covid-19. Semua peserta dan panitia terlebih dahulu mencuci tangan sebelum masuk ke lokasi pelatihan. Selain itu peserta juga diberikan masker dan dipakai selama kegiatan.

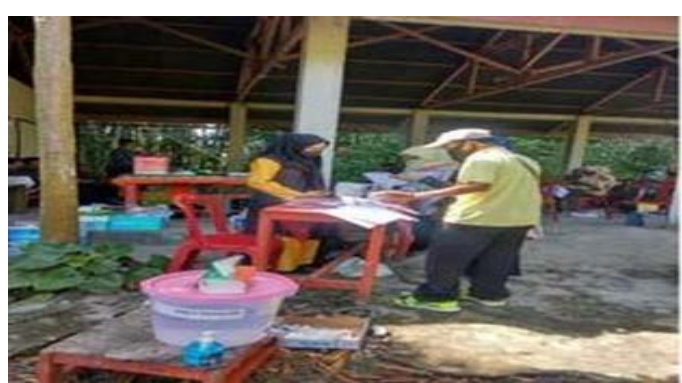

Gambar 3. Peserta menerapkan Protokol Covid 19

Kegiatan ini dilakukan dalam bentuk ceramah atau pemaparan materi. Penyaji memberikan materi dengan menggunakan metode ceramah yang disertai dengan diskusi atau tanya jawab dengan peserta. Semua materi disampaikan dengan menggunakan slide persentasi.

Pada kegiatan penyuluhan ini disampaikan materi tentang reparasi mesin jahit. Materi diawali dengan penjelasan tentang sejarah mesin jahit dari masa ke masa. Selanjutnya dijelaskan beberapa hal tentang permasalahan permasalahan yang sering dijumpai pada mesin jahit seperti mesin tidak lancar dan sering berisik, benang yang sering putus baik benang bagian atas atau bawah, jerat benang yang mengkerut, jerat benang yang kendur, jarum jahit yang sering patah dan pergerakan kain atau objek jahitan yang sering tidak lancar. Dari kondisi kondisi tersebut kemudian dijelaskan penyebab terjadinya serta bagaimana cara memperbaikinya.

Selain itu disampaikan juga tentang tips-tips perawatan mesin jahit terutama masalah pelumasan dan pengaturan (setting) alat supaya menghasilkan jahitan yang bagus. Di bagian akhir pemaparan dilakukan diskusi dengan peserta pelatihan mengenai materi yang telah disampaikan.

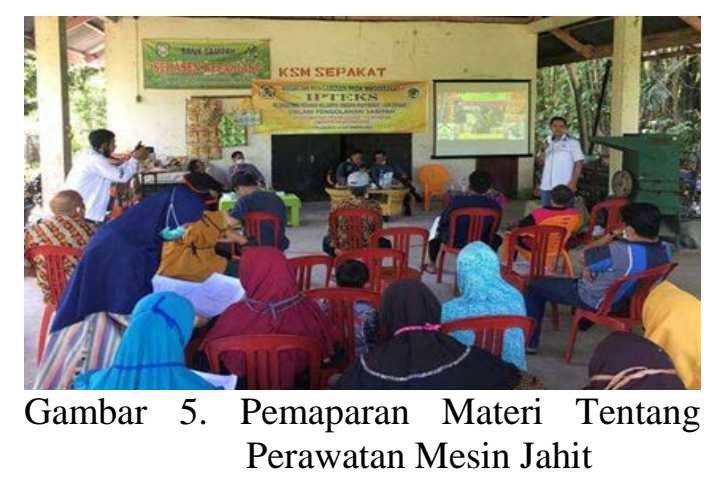

Tahap berikutnya adalah pelatihan tentang reparasi mesin jahit. Kegiatan ini dilakukan untuk memantapkan teori yang disampaikan ketika penyuluhan sebelumnya. Pemateri menjelaskan kembali tentang beberapa kendala kendala yang sering ditemui pada mesin jahit dan memperlihatkan beberapa komponen yang sering mengalami kerusakan. Setelah diperlihatkan beberapa contoh komponen rusak tersebut, kemudian dilanjutkan dengan cara mengatasinya.

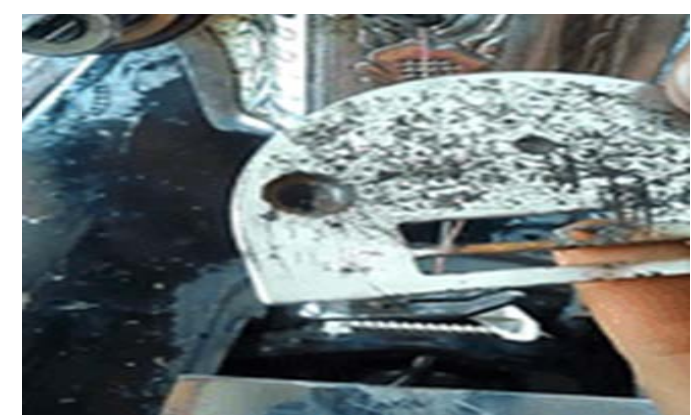

Gambar 6. Contoh Komponen yang Rusak

Selain itu juga dijelaskan bagian bagian yang wajib dilumasi serta cara pemberiannya. Kegiatan dilakukan tidak terlalu formal sehingga peserta menjadi lebih aktif dalam bertanya langsung atau mencoba trik-trik yang telah diberikan oleh instruktur. 


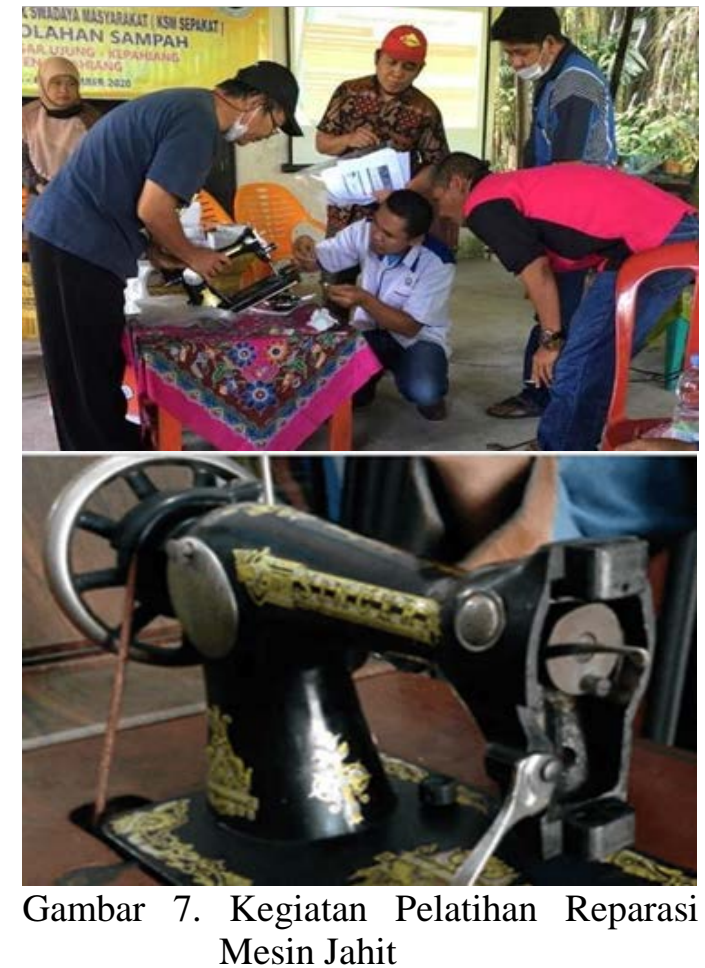

Tahap tearakhir dari kegiatan pengabdian masyarakat ini adalah melaksanakan evaluasi dan monitoring secara intensif dan berkelanjutan. Supaya kegiatan di KSM ini berkelanjutan setelah diadakan pelatihan maka dilakukanlah kegiatan pendampingan. Kegiatan ini bertujuan untuk memotivasi mereka supaya ilmuilmu yang telah diperoleh ketika penyuluhan dan pelatihan dapat diterapkan sehingga kegiatan di KSM dapat hidup kembali.

Dari kegiatan yang telah dilakukan, secara umum peserta sangat antusias dalam mengikuti setiap sesi acara. Hal tersebut terlihat dari partisipasi selama acara dan dari data kuisioner peserta (tabel 1).

Dari hasil kuisioner pada tabel 1 di atas terlihat bahwa secara umum peserta dapat memahami apa yang disampaikan oleh instruktur pelatihan. Selain itu materi juga disampaiakn dengan baik walaupun masih ada sekitar 16,7 persen yang masih ragu-ragu apakah contoh kasus yang disampaikan sudah sesuai dengan kondisi lapangan. Selain itu kepada peserta juga disurvei apakah mereka akan mendukung dan berpartisipasi aktif dalam mengembangkan usaha kerajinan daur ulang sampah plastik di lingkungan masing masing. Dari jawaban peserta semuanya menyatakan setuju dan sangat setuju dengan pernyataan tersebut dan menyatakan mereka siap untuk mendukung serta berpartisipasi aktif dalam kegiatan kerajinan daur ulang sampah. Jawaban kesiapan peserta dalam mendukung program pendaur ulangan sampah ini menjadi modal besar untuk pengembangan KSM selanjutnya. Selain itu pada kuisioner juga ditanyakan apakah peserta mempunyai mesin jahit dirumah masing-masing. Dari jawaban peserta hanya 46,7 persen yang memiliki mesin jahit di rumahnya. Dari kuisioner juga terlihat bahwa sebagian besar meyakini kalau kegiatan pengolahan sampah plastik akan menjadi usaha alternatif bagi ibu ibu sekaligus menambah pendapatan keluarga, walaupun masih ada 26,7 persen yang masih ragu-ragu. Termasuk ketika dimintakan pendapat mereka tentang apakah hasil kerajinan daur ulang sampah mudah dipasarkan. Para peserta masih ada keraguan sekitar $46,7 \%$

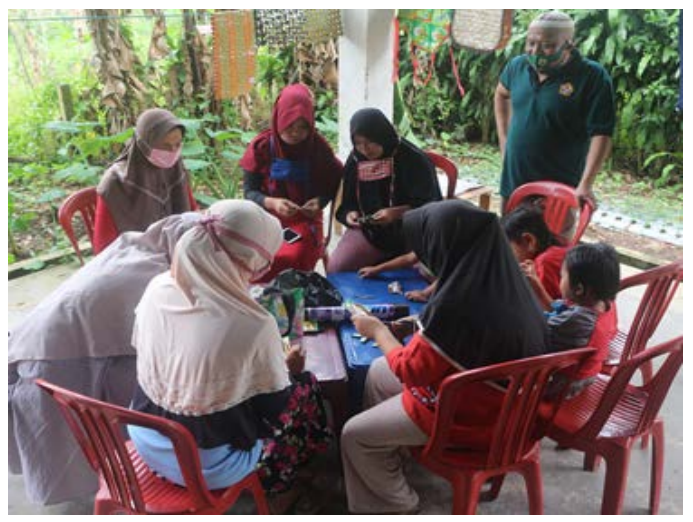

Gambar 7. Kegiatan Pendampingan 


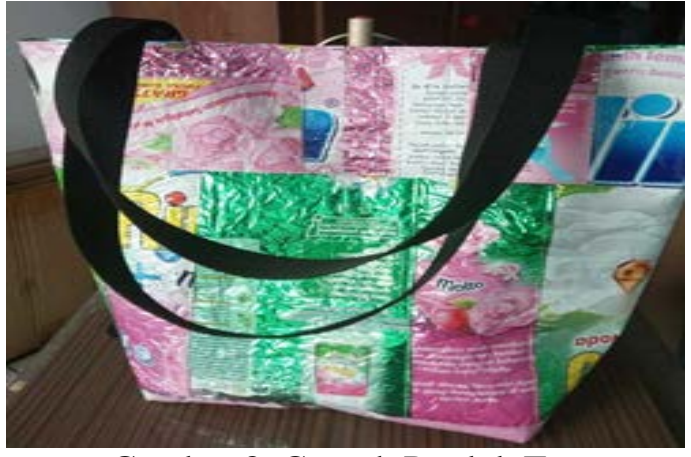

Gambar 8. Contoh Produk Tas

Tabel 1. Kuisioner Kegiatan Pelatihan

\begin{tabular}{|c|c|c|c|c|}
\hline NO & Pernyataan & $\begin{array}{l}\text { SS } \\
\text { (\%) }\end{array}$ & S (\%) & R (\%) \\
\hline 1. & $\begin{array}{l}\text { Materi kegiatan } \\
\text { reparasi mesin jahit } \\
\text { disampaikan dengan } \\
\text { baik dan jelas }\end{array}$ & 20 & 80 & 0 \\
\hline 2 & $\begin{array}{l}\text { Siap mendukung dan } \\
\text { berpartisipasi aktif } \\
\text { dalam } \\
\text { mengembangkan } \\
\text { usaha kerajinan daur } \\
\text { ulang sampah plastik }\end{array}$ & 83,3 & 16,7 & 0 \\
\hline 2. & $\begin{array}{l}\text { Materi kegiatan } \\
\text { reparasi mesin jahit } \\
\text { mudah dipahami }\end{array}$ & 20 & 80 & 0 \\
\hline 3. & $\begin{array}{l}\text { Contoh contoh kasus } \\
\text { yang disampaikan } \\
\text { sesuai dengan kondisi } \\
\text { lapangan }\end{array}$ & 0 & 83,3 & 16,7 \\
\hline 4. & $\begin{array}{l}\text { kegiatan pengolahan } \\
\text { sampah plastik akan } \\
\text { menjadi usaha } \\
\text { alternatif bagi ibu ibu } \\
\text { sekaligus menmabah } \\
\text { pendapatan keluarga }\end{array}$ & 13,3 & 60 & 26,7 \\
\hline 5 & $\begin{array}{l}\text { Hasil kerajinan daur } \\
\text { ulang sampah mudah } \\
\text { dipasarkan }\end{array}$ & 10 & 50 & 40 \\
\hline
\end{tabular}

Dari hasil kuisioner tersebut maka tim pengabdian telah memfasiltasi untuk melakukan kerjasama dengan CSR (Corporate Social Responsibility) PLN, Dinas Perindustrian, dan Dinas Lingkungan Hidup. Sehingga dengan adanya pembinaan dari CSR PLN tersebut memberikan keyakinan kepada anggota KSM Sepakat untuk kembali giat dalam usaha pendauran ulang sampah ini. Selain pembinaan dari dunia industri, pemerintah melalui Dinas Perindusrian dan Dinas
Lingkungan Hidup juga sudah menyatakan kesiapan mereka untuk membantu KSM Sepakat ini dalam hal pemasaran produk dan kebijakankebijakan lainnya

\section{SIMPULAN}

Dari kegiatan pengabdian yang telah dilakukan mulai dari observasi sampai dengan kegiatan pelaksanaan dan pendampingan maka dapat disimpulkan beberapa hal sebagai berikut :

1. Kegiatan telah berhasil dilaksanakan dengan baik yang terlihat dari antusias para peserta penyuluhan dan pelatihan

2. Kemampuan mereparasi sendiri mesin jahit sangat diperlukan oleh para perajin daur ulang sampah karena selama ini mereka terkendala oleh hal-hal demikian bisa menurunkan produktifitas mereka

3. Perawatan berkala terutama pelumasan sangat berpengaruh terhadap kendalan mesin jahit tersebut

4. Kegiatan pendampingan sekaligus pembinaan perlu tetap dilakukan untuk menjaga kesinambungan dari KSM Sepakat

5. Peran dunia usaha lewat CSR dan Pemerintah sangat diperlukan untuk meninggkatkan produktifikas dari KSM Sepakat.

\section{UCAPAN TERIMA KASIH}

Kegiatan Pengabdian Pada Masyarakat (PPM) ini dapat dilaksanakan dengan baik berkat bantuan berbagai pihak. Oleh karena itu pada kesempatan ini, diucapkan terima kasih kepada pihak yang turut membantu yaitu:

1. Pihak Lembaga Penelitian dan Pengabdian pada Masyarakat 
Ahmad Fauzan Suryono, dkk. Pelatihan Perawatan Mesin Jahit Dalam Rangka ...

Universitas Bengkulu yang telah memberikan kesempatan kepada tim pelaksana untuk melaksanakan kegiatan ini.

2. Kelompok Swadaya Masyarakat (KSM) Sepakat yang berlokasi di Kelurahan Pasar Ujung Kabupaten Kepahiang sebagai mitra kegiatan.

\section{DAFTAR PUSTAKA}

Asteria, Donna dan Heruman, Heru. 2016. Bank sampah sebagai Alternatif Strategi Pengelolaan Sampah Berbasis Masyarakat di Tasikmalaya. Jurnal Manusia dan Lingkungan 23 (1): $136-141$.

Ediana, Dina, Fitria Fatma dan Yuniliza.2018. Analisis Pengolahan Sampah Reduce, Reuse, Recycle (3R) pada Masyarakat di Kota Payakumbuh. Jurnal Endurance 3 (2) : 238-246.

Kurnia, Nining. 2019. Sampah Menjadi Masalah Lingkungan di Indonesia. https://www.kompasiana.com. Diakses Tanggal 01 April 2020 Pukul 15.50 WIB.

Nugroho, Cahyo Aji, Rully Agus Hendrawan dan Hafidz,Irma.
2012. Clustering Kelompok Swadaya Masyarakat (KSM) dalam Menentukan Kebijakan Bantuan Badan Pemberdayaan Masyarakat di Kota Surabaya dengan Menggunakan Metode Self-Organizing Map (SOM) dan K-Means. https://www.researchgate.net. Diakses Tanggal 01 April 2020 Pukul 16.00 WIB.

Permata, Lintang .2017 Optimalisasi Pengelolaan Sampah Pesisir Untuk Mendukung Kebersihan Lingkungan Dalam Upaya Mengurangi Sampah Plastik. Jurnal Pengabdian Masyarakat Universitas Padjajaran Vol.1, No. 1 Februari 2017 : 14-18

Pusat Penelitian dan Pengembangan Permukiman Balitbang Kementerian Pekerjaan Umum RI. (2010). Modul Pengolahan Sampah Berbasis 3R.

http://litbang.pu.go.id/puskim. Diakses Tanggal 02 April 2020 Pukul 14.05 WIB. 